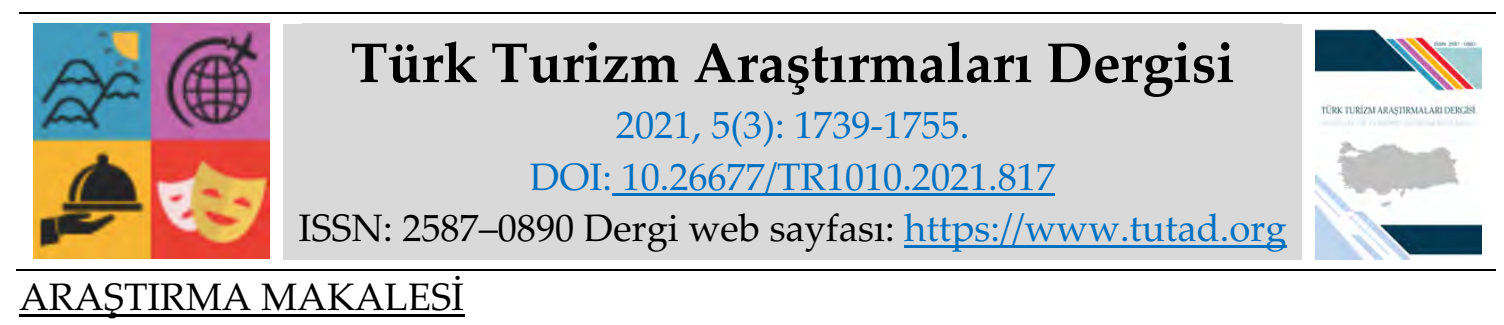

\title{
Geleneksel Pişirme Tekniklerinin Koronavirüse Yakalanma Üzerine Etkisi
}

Ali Kemal ÇífTÇİ, Sivas Numune Hastanesi, Beslenme ve Diyet Polikliniği, Sivas, e-posta: alikemal.ciftci@saglik.gov.tr ORCID: https://orcid.org/0000-0002-2812-0480

Doç. Dr. İbrahim Tuğkan ŞEKER, Sivas Cumhuriyet Üniversitesi, Turizm Fakültesi, Sivas, eposta: tseker@cumhuriyet.edu.tr

ORCID: https://orcid.org/0000-0003-3695-9750

\section{Öz}

Koronavirüs hastalığına yakalanmada birçok faktör etkili olmaktadır. Bunların başında maske takılmaması, sosyal mesafe kurallarına uyulmaması, hijyen kurallarına dikkat edilmemesi gelmektedir. Yapılan bu çalışmada ise besinleri hazırlama, pişirme ve saklama uygulamalarına bağlı olarak bireylerin koronavirüs hastalığına yakalanma durumlarını ortaya koymak amaçlanmıştır. Çalışmanın örneklem kümesini besinlere yönelik uygulamalarda aktif rol alan 625 birey oluşturmaktadır. Çalışmaya katılan bireylerin \%30 ( $\mathrm{n}=189$ )'unun PCR (Polymerase Chain Reaction) tarama testi veya BT (Bilgisayarlı Tomografi) yöntemi test sonucunun pozitif olduğu ortaya konulmuştur. Çalışmaya katılan bireylerin araştırma verileri çevrimiçi anket yöntemiyle toplanmıştır. Veriler SPSS 23.0 paket veri programında değerlendirilip, istatistiksel analizde ANOVA Testi ve Ki-kare $\left(\chi^{2}\right)$ önemlilik testi kullanılmıştır ve 0.05 'ten küçük $p$ değeri istatistiksel olarak anlamlı kabul edilmiştir. Çalışmaya katılan bireylerin, besinlere yönelik uygulamalara vermiş olduğu doğru cevaplar "1 Puan", yanlış cevaplar ise "0 Puan” olarak ölçeklendirilmiştir. Analiz sonuçlarına göre en düşük puan olan birey 3 puan, en yüksek puan alan birey ise 14 puan almıştır. Bireylerin doğru yapma ortalamaları ise $8,88^{\prime}$ dir. Çalışma sonuçlarına göre bireylerin koronavirüs hastalığına yakalanma oranının azalması ile besinlere yönelik doğru yöntemleri uygulamaları arasında anlamlı bir fark bulunmuştur $(p<0,05)$. Ayrıca koronavirüs hastalığına yakalanma oranı ile cinsiyet ve aylık gelir düzeyleri arasında da anlamlı bir fark bulunmuştur $(p<0,05)$. Başta koronavirüs olmak üzere bulaşıcı hastalıklardan korunmak için dikkat edilmesi gereken hususlar arasında besinlere yönelik satın alma, hazırlama, pişirme ve saklama aşamalarında doğru yöntemlerin uygulanması da gösterilebilir.

* Bu makale araştırmacı tarafından Sivas Cumhuriyet Üniversitesi Sosyal Bilimler Enstitüsü Sağlık Turizmi İşletmeciliği Ana bilim dalında kabul edilen "Koronavirüs Döneminde Bireylerin Besinleri Hazırlama, Pişirme ve Saklama Uygulamaları" adlı Yüksek Lisans Tezinden uyarlanmıştır.

Anahtar Kelimeler: Covid-19 ve Beslenme, Besinleri Hazırlama, Pişirme, Saklama.

Makale Gönderme Tarihi: 13.06.2021

Makale Kabul Tarihi: 04.09.2021

\section{Önerilen Atıf:}

Çiftçi, A. K. ve Şeker, İ. T. (2021). Geleneksel Pişirme Tekniklerinin Koronavirüse Yakalanma Üzerine Etkisi, Türk Turizm Araştırmaları Dergisi, 5(3): 1739-1755.

(c) 2021 Türk Turizm Araştırmaları Dergisi. 


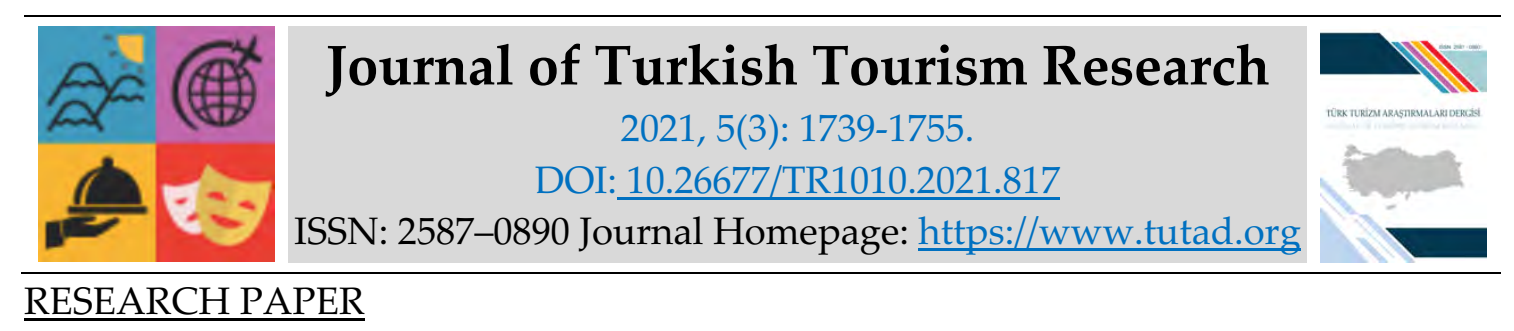

\title{
The Effect of Traditional Cooking Techniques on Getting Coronavirus
}

\author{
Ali Kemal ÇífTÇİ, Sivas Numune Hospital, Nutrition and Diet Polyclinic, Sivas, e-mail: \\ alikemal.ciftci@saglik.gov.tr \\ ORCID: https://orcid.org/0000-0002-2812-0480
}

Associate Prof. Dr. İbrahim Tuğkan ŞEKER, Sivas Cumhuriyet University, Faculty of Tourism, Sivas, e-mail: tseker@cumhuriyet.edu.tr

ORCID: https://orcid.org/0000-0003-3695-9750

\begin{abstract}
Many factors are effective in catching coronavirus disease. These include not wearing masks, not following social distance rules, and not paying attention to hygiene rules. This study, it was aimed to reveal the situation of individuals catching coronavirus disease depending on food preparation, cooking, and storage practices. The sample set of the study consists of 625 individuals who take an active role in food applications. It was revealed that $30 \%(n=189)$ of the individuals participating in the study had positive PCR (Polymerase Chain Reaction) screening test or CT (Computerized Tomography) method test results. Research data of the individuals participating in the study were collected by online survey method. The data were evaluated in the SPSS 23.0 package data program, ANOVA Test, and Chi-square $(\chi 2)$ significance test were used to statistical analysis, and a $p$-value less than 0.05 was considered statistically significant. The correct answers given by the individuals participating in the study to the applications related to foods were scaled as "1 Point" and the wrong answers as "0 Points". According to the results of the analysis, the individual with the lowest score received 3 points, and the individual with the highest score received 14 points. The average correctness of individuals is 8.88 . According to the results of the study, a significant difference was found between the decrease in the rate of catching coronavirus disease and the application of the right methods for food $(p<0.05)$. In addition, a significant difference was found between the rate of contracting coronavirus disease and gender and monthly income levels $(p<0.05)$. Among the issues to be considered to protect from infectious diseases, especially coronavirus, the application of the right methods during the purchasing, preparation, cooking, and storage stages of foods can be shown.
\end{abstract}

Keywords: Covid-19 and Nutrition, Food Preparation, Cooking, Storage.

Received: 13.06 .2021

Accepted: 04.09.2021

Suggested Citation:

Çiftçi, A. K. and Şeker, İ. T. (2021). The Effect of Traditional Cooking Techniques on Getting Coronavirus, Journal of Turkish Tourism Research, 5(3): 1739-1755.

(C) 2021 Türk Turizm Araştırmaları Dergisi. 


\section{Gíriş}

21. yüzyılda Çin'in Hubei eyaleti, Wuhan şehrinde 31 Aralık 2019 yılında ortaya çıkan koronavirüs tüm dünyayı etkisi altına alarak pandemi ilan edilmesine neden olmuştur (WHO, 2021). Chan vd., (2020) koronavirüsün solunum, damlackk ve virüsün bulunduğu yüzeylere temas edilmesi sonucu virüsün vücuda alındığını belirtmiştir. Virüsü içerebilen ve her gün en çok temasta bulunulan yüzeyler arasında besinlerin bulunduğu söylenebilir.

Bir tarım ülkesi olan Türkiye'de sağlıklı beslenme oranı diğer ülkelerle karşılaştırıldığında normal düzeylerde olmasına rağmen beslenmeye bağlı sağlık sorunları görülmektedir (Baysal, 1999). Bu sorunların başlıca sebepleri arasında düşük gelir düzeyi ve hayvansal gıda tüketiminin yetersiz olduğunu gösteren çalışmalar (Güneyli ve Yücecan, 1987:18-25) olsa da Tezcan (1985)'ın yaptığ1 çalışmada ise kötü beslenmenin sebebinin besin yetersizliği ve gelir yetersizliğinin yanında, besinleri satın alma, hazırlama, pişirme ve saklama yöntemlerindeki alışkanlıklara bağlı olabileceğini düşündürmektedir.

Baysal (1990) bireylerin besinleri satın alma, temizleme, pişirmeye hazırlık, pişirme ve saklama konularında faydadan çok genellikle damak zevkini ön planda tuttuğunu belirtmiştir. Örneğin; bazı bireyler damak zevkine uygun olmadığı gerekçesi ile pişirme suyunu dökmektedir. Bunun sonucunda suda çözünen ve vücut için faydalı olan vitaminlerin ve minerallerin pişen yemekten uzaklaştırılmasına sebep olmaktadır (Ateş vd., 1986). Yine benzer sebepten dolayı sütün olması gerekenden fazla kaynatılması, yoğurt mayalandıktan sonra suyunun süzülmesi veya yoğurdun ışık alan bir yerde bekletilmesi gibi hatalı uygulamalar besinlerdeki bazı vitamin değerlerinde kayıplara yol açmaktadır (Baysal 1988). Bununla birlikte toplumdaki kültürel değişiklik ve farklı inanışlara bağlı olarak da besin ilkeleri açısından yanlış ve zararlı yöntemler uygulayan birey sayısı da oldukça fazladır. Örneğin bazı bireyler yaz aylarında sütün ishal yaptığı inancıyla süt tüketme konusunda çekimser davranmaktadır. Bazı toplumlarda ise et iyice pişirildiği zaman besin değerini yitireceği düşüncesiyle eti yeterince pişirmeden tüketmektedir (Yücecan, 1989).

Teknolojinin gelişmesi ve toplumdaki kültürel değişim sonucu ortaya çıan beslenme alışkanlıkları arasında faydalı olanlar olduğu gibi zararlı olanlar da vardır. Son yıllarda beslenme bilimi hızla geliştiği halde beslenmeye bağlı sorunlar ortaya çıkmaktadır. Bu sorunların tespit edilmesi ve çözülebilmesi için beslenme alışkanlıklarının tespit edilmesi gerekmektedir (Vashfam, 2002).

Besinlerin satın alınması, hazırlanması, pişirilmesi, saklanması ile ilgili davranışlar öğrenilmiş davranışlardır. Öğrenilmiş davranışların değiştirilmesi her ne kadar zor ve yavaş işlese de bireylere fayda sağlaması açısından bu davranışların değiştirilmesi beslenme ilkelerinde önemli bir yere sahiptir (Ersoy, 1999).

Yeterli düzeyde beslenmenin sağlanamamasında ve hastalıkların ortaya çıkmasında çevresel ve dış faktörlerin yanında besinlerin satın alınması, pişirilmesi ve saklanmasında yapılan yanlışlar da etkilidir. Yiyecekleri hazırlama ve pişirmedeki amaç; besinlerdeki zararlı mikroorganizmaları yok etmek, besin değerlerini mümkün olduğunca koruyarak, renk, tat ve koku olarak uygun biçimde tüketilebilir forma getirmektir (Malatyalığlu, 1991).

\section{KAVRAMSAL ÇERÇEVE Besin Gruplarını Satın Alma}

Ambalajsız, çiğ veya açıkta satılan ürünler tercih edilmemelidir. Bu ürünler hazırlanırken soğuk zincir kuralları ihmal edilmiş olabileceğinden insan sağlı̆̆ını tehdit eden mikroorganizmaların 
çoğalması görülebilir. Ayrıca üretim yapılan yerde uygun hazırlama, pişirme veya isıtma yöntemleri uygulanmadığı için satın alınacak ürünlerde renk, koku, tat gibi besin tüketimini engelleyen fiziksel veya kimyasal değişiklikler görülebilmektedir (Baysal, 2002).

Süt ürünleri satın alınırken kapalı ambalajlı ürünler tercih edilmelidir. Ürün standardının işareti ve numarası, imal tarihi ve son kullanma tarihi, net veya brüt ağırlığı, üretici firma adı bilgilerinin ambalaj üzerinde bulunmasına dikkat edilmelidir. Açık kurubaklagil ürünler alınması her ne kadar tavsiye edilmese de tercih edileceği zaman nemli, küflü, rengi bozulmuş, içerisinde kum, taş, kurtçuk olan, ezilmiş ve çürümüş ürünler tercih edilmemelidir (Baysal, 1990).

Etler alınırken doğal renginin korunmuş olmasına dikkat edilmelidir. Yüzeyinde yapışkanlık, kir ve dışkı kalıntısı bulunmamalıdır. Soğuk depolarda çok beklemesi sonucu yüzeyinde kahverengileşme olmamalıdır. Parça halinde bulunuyorsa kan birikmesi veya sulanma durumu olmamalıdır. Kendine has kokusu olmalı, temizlik maddesi, dezenfektan vs. kokusu bulunmamalıdır. Vakumlu pakette satılıyorsa vakum özelliğinin kaybolmuş olmaması gerekmektedir. Etlerin bulunduğu dolapların veya reyonların sıcaklığı et normal ise $+4^{\circ} \mathrm{C}^{\prime}$ nin üzerinde olmamasına, donuk halde ise $-18^{\circ} \mathrm{C}^{\prime}$ nin altında olmasına dikkat edilmelidir (Çıltık, 2009). Balıklar alınırken solungaçlarının temiz, kokusuz, kırmızı renkte ve nemli olmasına dikkat edilmelidir. Taze balıkların pulları yapışık ve parlak olmaktadır. Bütün haldeki balık suya atıldığında batması da balığın tazelik göstergelerindendir. Bayat olan etlerin toksisitesi çok fazladır. Bu sebeple et alırken taze olmasına dikkat edilmelidir. Ayrıca et ürünleri alışverişte en son sırada alınmalıdır (Dönmez vd., 2012). Sebze ve meyveleri satın alırken pürüzsüz, düzgün, pörsümemiş, doğal görünümlü, rengi canlı ve parlak olan mevsim ürünleri tercih edilmelidir. Ayrıca sebzeler taze, çürümemiş ve standart büyüklükte olmalıdır. İçerisinde çamur, toprak, toz bulunmamalıdır. Zedelenmiş, ezilmiş ve yıpranmış ürünler alınmamalıdır. Tat, koku ve lezzet olarak organoleptik özellikleri taşımalıdır. Çimlenme, renk değişimi, küflenme ve böcek yeniği bulunmamalıdır (Çelebi, 2014). Satın alınacak yağın rengi açık sarı ve berrak olmalıdır. Normal ısıda içerisinde tortu bulunmamalıdır. Yağın elde edildiği bitkiye göre yağın rengi değişebilmektedir. Rafine ünitesinin işleme metodu ve teknolojisi yağın kalitesini belirlemektedir. Rafine işlemleri esnasında sabun ve alkali kullanılmamalıdır. Kutularında delik, çatlak ve hasar bulunmamalıdır. Ambalajların üzerinde yağın cinsi, üretici firma adı, üretim ve son kullanma talimatı, gramajı ve TSE (Türk Standartları Enstitüsü) damgası bulunmalıdır (Baysal, 2013).

\section{Besin Gruplarını Pişirme}

Besinlerin ısıya maruz kalması sonucunda renk, tat, şekil, koku, aroma, doku değişimi veya besinsel içeriklerin ortaya çıkması gibi fiziksel ve kimyasal değişikliklere pişirme denilmektedir (Bulduk, 2002). Bu değişikliklerin ortaya çıkması sonucunda ürün çeşitlilikleri sağlanmakta olup, bu durum aynı zamanda tüketicilerin ürünü tercih etmesinin önünü açmaktadır. Son yıllarda tüketiciler açısından besinlerin pişirilme yöntemleri merak edilmektedir. Özellikle çocuklarda, diyet yapan bireylerde, şeker hastalarında, tansiyon hastalarında ve yaşlılarda besinlerin tercih edilmesinde pişirme yöntemleri etkili olmaktadır (Sökmen, 2011).

Isıyla etkileşime giren gidalarda fiziksel ve kimyasal ve değişimler; yiyeceklerin tat, renk, koku, doku ve besinsel değerlerinde değişiklikler ortaya çıarmaktadır (Eryılmaz, 2004). Yiyecekler üzerinde bu farklılaşmaların sebep olduğu değişimler, yiyecek içecek üretimi yapan işletmelerde ürün çeşitliliğini oluşturarak bireylerin yiyecekleri tercih etmelerinde etkili olmaktadır. Besin gruplarında doğru pişirme yöntemleri kullanıldığı takdirde gıdaların lezzetini ve kalitesini artırmak mümkün olmaktadır. Her besin farklı yapısal özelliklere sahip olabileceğinden bunlara 
özgü doğru pişirme yöntemlerinin uygulanması besinlerin tüketilme oranını arttırmaktadır (Dölkeleş, 2010).

Maviş (2008)'e göre yiyecekleri pişirmenin amaçları arasında besine tat ve lezzet katmak, yapısal değişikliğine olumlu biçimde katkı sağlamak, sindirim organlarını harekete geçirmek, iştahı açmak ve patojen (zararlı) mikroorganizmaları ortadan kaldırmak olarak açıklanmaktadır.

Besinleri pişirme ve saklamada kullanılan kaplar besin kalitesini ve besinden yararlanma derecesini etkilemektedir. Besinlerden meydana gelecek zararlardan ve kanser yapicı etkilerinden korunmak için alınacak tedbirler besinlerin pişirme ve saklanmasında kullanılacak kap tercihinin önemini açığa çıkarmaktadır (Gürman, 2006). Mutfakta yemek yapmaya uygun pek çok boyutta ve farklı malzemelerden yapılmış pişirme kapları bulunmaktadır. Her bir kap kullanılacağı alana göre elverişli ya da elverişsiz olabilir. Yemek yapılan kaplarda kullanılan malzemeler incelendiğinde demir, çelik, alminyum, bakır, emaye, seramik, Teflon ve cam gibi çeşitlerine rastlamak mümkündür (Aktaş, 2001).

Pişirme yönteminin belirlenmesinde sadece gıdanın besin değerinin korunmasını sağlamak; görünüşü, kokusu ve lezzeti ile yemek yeme isteği uyandırmak değil, enerjiyi ve süreyi de en iyi biçimde değerlendirerek maliyetten de tasarruf etmektir. Aşçlık ve pişirmenin değişimi geçmişten günümüze insanların keşfettikleri yöntemlere dayanmaktadır. Bu yöntemler arasında sulu pişirme teknikleri ve kuru pişirme teknikleri kullanılmaktadır. Besinlerin pişirilmesinde bu yöntemler tek başına kullanılabildiği gibi birlikte de kullanılabilmektedir. Yiyeceğin nasıl pişirilmesi gerektiği, içeriğine ve 1sı kaynağının türüne göre değişebilmektedir (Hunter ve Tinton, 2011).

Sulu pişirme yöntemi, pişirme yöntemleri içerisinde diğer yöntemlere göre en kolay yöntem sulu pişirme yöntemidir. Bu yöntemde tercih edilecek suyun miktarını tercih edilen besin ve pişirme kabının boyutu belirlemektedir. Bu yöntemde yiyeceklerin ısıtılması veya pişirilmesi sos veya su yardımıyla olmaktadır. Pişirme yönteminin adlandırılması ise suyun ısıtıldığı sıcaklık değerine göre değişebilmektedir. Sağlıklı beslenme açısında değerlendirildiğinde kızartma veya kavurma yöntemlerine göre daha çok tercih edilen bir yöntemdir (Türkan, 2012).

Kuru (susuz) pişirme yöntemleri Yiyeceklerin etrafında sıcak hava dolaşımı ile az yağlı tavada ve kızgın tavada pişirilmesi, fırında pişirme, mikrodalga ile pişirme gibi yöntemlere dayanmaktadır. Yemeklerin kuru isıda pişirilmesinde farklı büyüklük ve çeşitte yemekler için farklı sıcaklıklarda ısılar ve farklı yöntemler gerekli olabilmektedir. Yağda pişirmeler az yağda sote veya derin yağda kızartma işlemlerinde kullanılır. Izgara yöntemi ile pişirmede hem alttan hem üstten veya sadece alttan 1sı verilmesi işlemi bulunmaktadır. Fırında pişirme yöntemleri et ve hamurlu yemekler için değişiklik gösterebilmektedir. Et yemeklerinin fırında pişirilebilmesi için genellikle marinasyon işlemi gerekliyken, hamur işlerinin fırında pişirilebilmesi için yiyeceğin etrafında güçlü bir hava dolaşımı olması gerekmektedir (Gisslen, 2011).

Gelişen teknoloji ve üretilen yeni aletlerle birlikte geleneksel pişirme yöntemlerine yeni yöntemler de eklenmiştir. Bunlar arasında bain-marie, mikrodalga yöntem, kızllötesi işlemler, vakumlayarak pişirme gibi yöntemler bulunmaktadır (William, 2011).

\section{Besin Gruplarını Saklama}

Besinlerdeki istenmeyen enzimatik tepkimeler ve çevresel etkiler besinlerde bozulmalara sebep olabilmektedir. Besinleri bozulmadan saklayabilmek ve mevsiminde yetişmeyenleri daha ucuza temin edebilmek için farklı saklama yöntemleri geliştirilmiştir. Bu yöntemlerin amacı besinlerde 
oluşabilecek lezzet, görünüş, renk ve besin değerindeki azalmaların önüne geçebilmektir (MEGEP, 2012).

Hayvansal kaynaklı besinler başta olmak üzere hemen her besin yapısında doğal olarak mikroorganizma bulunabilmektedir. Besinler, tehlikeli 1sı aralığı üstündeki sıcaklıklara maruz bırakılarak patojen mikroorganizmaların üremesi ve çoğalmasının önüne geçilebilir. Ayrıca ısı kontrolünün sağlanmasıyla enzimatik faaliyetler de durdurulabilir. Isı derecesinin çok yükseltilmesi bazı patojen mikroorganizmaları yok edebileceği gibi, enzimlerin yapısında bozulmaya da yol açabilir (Kutlu, 2004).

Mikroorganizmaların ısıya dayanıklılıklarını çeşitli faktörler etkileyebilmektedir. Örneğin pH derecesi azaldıkça, yani bulundukları ortamın asitliği arttıkça bazı mikroorganizmaların ısıya karşı gösterdikleri direnç de azalmaktadır. Bu yüzden $p H$ derecesine bağlı olarak belirli bir süreyle uygulanan sıcaklık ile besinler daha dayanıklı hâle getirilebilmektedir. Basınç, sıcaklık, $p H$ gibi mikroorganizmaların üremesinde doğrudan etkili olan faktörlerde değişiklikler yapılmasını esas alan yöntemlerle besinlerin ömürleri ve dayanıklılık süresi artırılır. Bu yöntemler yapılırken isıl işlem uygulama, dondurma, kurutma, fermente etme, tütsüleme, baharat veya kimyasal madde kullanma ve vakumlama işlemleri kullanılır (Bulduk, 2004).

Besinlerin satın alınması, hazırlanması, pişirilmesi ve saklanmasında en uygun yöntemler bilinmediği ve uygulanmadığı takdirde besinlerde oluşan kayıpların önüne geçmek mümkün değildir. Bunun sonucunda besin değeri düşük gıdalar vücuda alınacak ve besin ögelerinin yetersizliği sonucu vücudumuzda bazı hastalıklar görülecektir (Malatyalıŏglu, 1991). Ancak Altay (1992)'a göre besinlerin satın alınmasından tüketilmesine kadar geçen aşamalar beslenme ilkelerine uygun şekilde gerçekleştirildiği takdirde beslenmeye bağlı hastalıkların görülme sıklığının azalacağı düşünülmektedir (Altay, 1992). Koronavirüs pandemisi döneminde besinleri satın alma, hazırlama, pişirme ve saklama aşamalarında doğru yöntemler uygulanmadığı takdirde, virüsün besinler yoluyla vücuda girdiği ve bireylerin koronavirüs hastalığına yakalandığı düşünülmektedir. Bireylerin besinleri satın alma, hazırlama, pişirme ve saklama uygulamalarında yanlış yöntemleri uygulamasıyla koronavirüs hastalığına yakalanması arasındaki ilişkiyi ortaya koymak amacıyla bu çalışma yapılmıştır.

\section{ARAŞTIRMANIN YÖNTEMI}

Bu çalışmanın evrenini Sivas ilinde yaşayan bireyler oluştururken, örneklem kümesini ise besinlerin satın alınmasından tüketilmesine kadar aktif rol alan 625 birey oluşturmaktadır. Konuyla ilgili daha önce yapılmış çalışmalardaki sorular, uzman görüşü alınarak katılımcıların daha iyi anlayabileceği hale dönüştürülerek anket formları oluşturulmuştur. Veriler Ocak 2021Mart 2021 tarihleri arasında toplanmış olup, sosyal mesafe kuralları ve sokağa çıkma kısıtlamalarının gerektirdiği sebeplerden dolayı online (çevrimiçi) anket yöntemi uygulanmıştır. Anket formunun ilk bölümde katılımclara ait demografik bilgilerden "yaş, cinsiyet, ailedeki birey sayısı, eğitim durumu, gelir düzeyi, meslek ve koronavirüs hastalığına yakalanıp yakalanmadığı" sorulmuştur. İkinci bölüm ise besinlerin hazırlama, pişirme ve saklamaya yönelik uygulamaları ortaya koymak için farklı soruları içermektedir. Araştırmanın geçerliliğini ölçmek için faktör analizi yapılmıştır. Ölçeklerin güvenilirliği için araştırma sorularına ve hipotezlerine uygun olarak Goodman-Kruskal'ın Lambda Katsayısına yer verilmiştir. Verilerin değerlendirilmesinde SPSS 23.0 lisanslı paket programı kullanılmıştır. Bulguların sonuçları tablolarda sayı (n) ve yüzde (\%) olarak belirtilmiştir. İstatistiksel analizlerde ANOVA Testi ve Ki- 
kare $\left(\chi^{2}\right)$ önemlilik testi kullanılmıştır ve $0.05^{\prime}$ ten küçük $p$ değeri istatistiksel olarak anlamlı kabul edilmiştir.

Makalede yer alan yazarlar makale sürecinde eşit katkılarda bulunmuştur. Yazarların bildirmesi gereken herhangi bir çıkar çatışması yoktur. Bu araştırmada kullanılacak verilerin toplanması için gerekli olan etik kurul izin belgesi Sivas Cumhuriyet Üniversitesi Etik Kurulu 21.01.2021 tarihi ve 2021/44 karar/sayı numarası ile alınmıştır.

\section{ARAŞTIRMA BULGULARI ve TARTIŞMA}

Bireylerin koronavirüs pandemisi döneminde besinleri hazırlama, pişirme ve saklamaya yönelik uygulamalarında ortaya çıkan değişikliklerin koronavirüs hastalığı ile ilişkisinin incelendiği bu çalışmaya 625 birey katılmıştır. Çalışmaya katılanların \%41'i erkek ve \%59'u kadındır. Çalışmaya katılanların \%1,4 (n=9)'ü ilkokul mezunu, \%5,9 (n=37)'u ortaokul mezunu, \%15,4 (n=96)'ü lise mezunu ve \%77,3 ( $\mathrm{n}=483)^{\prime} \dot{\mathrm{u}}$ üniversite mezunudur. Çalışmaya katılan bireylerin ailelerindeki birey sayıları incelendiğinde, \%19,8 ( $\mathrm{n}=124)^{\prime}$ inin ailesindeki birey sayısı 2 kişi ve daha az, \%67,8 $(\mathrm{n}=424)^{\prime}$ inin ailesindeki birey sayısı 3-5 kişi, \%12,3 (n=77)'ünün ailesindeki birey sayısı 6 kişi ve daha fazla olduğu belirlenmiştir. Çalışmaya katılan bireylerin \%2,4 $(\mathrm{n}=15)^{\prime}$ ü 20 yaş altında, $\% 49,8$ $(\mathrm{n}=311)^{\prime} \mathrm{i}$ ise 20-29 yaş aralığındadır. \%27,8 (n=174)'i 30-39 yaş aralığına sahipken, \%12,8 (n=80)'i $40-49$ yaş aralığındadır. 45 kişi ise $(\% 7,2) 50$ yaş ve üzerindedir. Çalışmaya katılan bireylerin $\% 42,6$ ( $\mathrm{n}=267$ )'sını doktor, diyetisyen, ebe, eczacı, fizyoterapist, hemşire ve psikolog gibi sağlık çalışanları oluştururken, \%57,4 ( $\mathrm{n}=358)^{\prime}$ ünü ise akademisyen, avukat, memur, mühendis ve öğretmen gibi diğer meslek grupları oluşturmaktadır.

Çalışmaya katılan bireylerin \%61,3 (n=383)'ü aylık 5000 TL ve üzeri gelire sahipken, \%38,7 $(\mathrm{n}=242)^{\prime}$ si ise 5000 TL altı gelire sahiptir. Çalışmaya katılan bireylere pandemi sürecinin başlamasından itibaren günümüze kadar PCR (Polymerase Chain Reaction) tarama testi veya BT (Bilgisayarlı Tomografi) yöntemi ile koronavirüs tanısı alıp almadıkları sorulmuştur. Bireylerin $\% 30,2(n=189)^{\prime}$ 'si bu iki yöntemden biriyle koronavirüs tanısını aldığını belirtirken, \%69,8 ( $\left.n=436\right)^{\prime} i$ ise daha önce koronavirüs hastalığına yakalanmadığını belirterek soruya "hayır" cevabını vermiştir.

Yapılan bu çalışmanın anket formunda besinleri satın alma, hazırlama, pişirme, hazırlama ve saklama aşamalarında bireylere seçenekler arasından, mikrobiyal risk etkenlerinin ortadan kaldırılması ve besin kalitesinin korunması açısından, doğru ve yanlış yöntemlerden hangisini tercih ettikleri sorulmuştur. Elde edilen çalışma verilerinin sonuçlarıyla bireylerin koronavirüs hastalığına yakalanması arasındaki ilişki incelenmiştir.

Yapılan bu çalışmaya katılan bireylere besin gruplarından sebzeleri pişirmeye hazırlık aşamasında bireylere sırasıyla "Önce yıkama sonra ayıklama”, "Önce ayıklama sonra yıkama”, "Önce doğrama sonra yıkama" uygulamalarından hangi işlemi uyguladıkları sorulmuştur. Araştırmaya katılan 625 bireyin \%61,8 (n=386)'i besinlerin pişirilmeden önce sağlıklı bir şekilde arındırılması için doğru olan "önce ayıklayıp sonra yıkama" uygulamasını yaparken, \%38,2 $(\mathrm{n}=239)^{\prime}$ sinin bu uygulamayı yanlış yaptığı ortaya konulmuştur.

Baysal (2002) sebzelerin pişirilmeye hazırlanması aşamasında ayıklayıp doğradıktan sonra yıkanmasıyla suda eriyen vitaminler olan $B$ grubu ve $C$ vitaminlerinde kayıpların olabileceğini belirtmiştir. Bu yüzden yapılması gereken en doğru uygulamanın yıkadıktan sonra doğrama işleminin olduğunu vurgulamıştır. Ayrıca Ayaz Topçu vd., (2003) sebzelerde meydana gelen en büyük besinsel kaybın sebepleri arasında kesme ve doğrama işleminden sonra yıkama işleminin yapılması olduğunu belirtmişlerdir. 
Tablo 1. Ölçeklendirilen Sorulara Verilen Cevapların Yüzdesi

\begin{tabular}{|c|c|c|c|}
\hline \multirow{2}{*}{\multicolumn{2}{|c|}{ SORU İFADELERİ }} & \multicolumn{2}{|c|}{ VERILEEN CEVAP } \\
\hline & & \multirow{2}{*}{$\begin{array}{c}\text { Yanliş } \\
239 \\
\end{array}$} & \multirow{2}{*}{$\frac{\text { Doğru }}{386}$} \\
\hline Sebzeleri pişirmeye hazırlarken izlenen sıraya ilişkin & $\mathrm{n}$ & & \\
\hline uygulama & $\%$ & $\% 38,2$ & $\% 61,8$ \\
\hline \multirow{2}{*}{ Sebze pişirmeye başlarken tercih edilen uygulama } & $\mathrm{n}$ & 295 & 330 \\
\hline & $\%$ & $\% 47,2$ & $5 \% 2,8$ \\
\hline \multirow{2}{*}{ Sebzeleri pişirirken kullanılan yöntem } & $\mathrm{n}$ & 407 & 218 \\
\hline & $\%$ & $\% 65,1$ & $\% 34,9$ \\
\hline \multirow{2}{*}{ Sebzeleri haşlarken uygulanan yöntem } & $\mathrm{n}$ & 445 & 180 \\
\hline & $\%$ & $\% 71,2$ & $\% 28,8$ \\
\hline \multirow{2}{*}{$\begin{array}{l}\text { Sebze ve meyveleri kışın kullanmak üzere kurutma } \\
\text { yöntemi }\end{array}$} & $\mathrm{n}$ & 542 & 83 \\
\hline & $\%$ & $\% 86,7$ & $\% 13,3$ \\
\hline \multirow{2}{*}{ Patatesi haşlama yöntemi } & $\mathrm{n}$ & 244 & 398 \\
\hline & $\%$ & $\% 39,0$ & $\% 61,0$ \\
\hline \multirow{2}{*}{ Eti çözdürmede izlenen yol } & $\mathrm{n}$ & 381 & 244 \\
\hline & $\%$ & $\% 61,0$ & $\% 39,0$ \\
\hline \multirow{2}{*}{ Eti saklamada tercih edilen yöntem } & $\mathrm{n}$ & 89 & 536 \\
\hline & $\%$ & $\% 14,2$ & $\% 85,8$ \\
\hline \multirow{2}{*}{$\begin{array}{l}\text { Izgara yaparken etle ateş arasında bırakılan mesafenin } \\
\text { uygunluğu }\end{array}$} & $\mathrm{n}$ & 533 & 92 \\
\hline & $\%$ & $\% 85,5$ & $\% 14,7$ \\
\hline \multirow{2}{*}{$\begin{array}{l}\text { Et ve balık ürünlerini yağda kızartma yönteminin } \\
\text { uygunluğu }\end{array}$} & $\mathrm{n}$ & 242 & 383 \\
\hline & $\%$ & $\% 38,7$ & $\% 61,3$ \\
\hline \multirow{2}{*}{$\begin{array}{l}\begin{array}{l}\text { Pilav ve helva yaparken kullanılan yöntemin } \\
\text { uygunluğu }\end{array} \\
\end{array}$} & $\mathrm{n}$ & 552 & 73 \\
\hline & $\%$ & $\% 88,3$ & $\% 11,7$ \\
\hline \multirow{2}{*}{ Makarnayı pişirme yönteminin uygunluğu } & $\mathrm{n}$ & 432 & 193 \\
\hline & $\%$ & $\% 69,1$ & $\% 30,9$ \\
\hline \multirow{2}{*}{$\begin{array}{l}\text { Yumurtayı kaynattıktan sonra bekletme yönteminin } \\
\text { uygunluğu }\end{array}$} & $\mathrm{n}$ & 177 & 448 \\
\hline & $\%$ & $\% 28,3$ & $\% 71,7$ \\
\hline \multirow{2}{*}{ Sütü saklama yöntemi } & $\mathrm{n}$ & 85 & 540 \\
\hline & $\%$ & $\% 13,6$ & $\% 86,4$ \\
\hline \multirow{2}{*}{ Sütü pişirme yöntemi } & $\mathrm{n}$ & 252 & 373 \\
\hline & $\%$ & $\% 40,3$ & $\% 59,7$ \\
\hline \multirow{2}{*}{ Sütü pişirdikten sonra yapılan yöntemin uygunluğu } & $\mathrm{n}$ & 426 & 199 \\
\hline & $\%$ & $\% 68,2$ & $\% 31,8$ \\
\hline \multirow{2}{*}{ Yoğurt alırken tercih edilen yoğurt çeşidi } & $\mathrm{n}$ & 133 & 492 \\
\hline & $\%$ & $\% 21,3$ & $\% 78,7$ \\
\hline \multirow{2}{*}{ Peyniri saklama yönteminin uygunluğu } & $\mathrm{n}$ & 69 & 556 \\
\hline & $\%$ & $\% 11,0$ & $\% 89,0$ \\
\hline
\end{tabular}

Yapılan bu çalışmaya katılan bireylere besin gruplarından sebzeleri pişirmede "Çiğgden pişirme", "Haşladıktan sonra pişirme", "Kavurarak pişirme" ve "Kızartarak pişirme" yöntemlerinden hangi uygulamayı tercih ettikleri sorulmuştur. Araştırmaya katılan bireylerin \%52,8 (n=330)'i 
doğru olan yöntemi tercih ederken, \%47,2 ( $\mathrm{n}=295)$ 'sinin farklı pişirme uygulamalarını tercih ettikleri ortaya konulmuştur.

Yapılan bu çalışmaya katılan bireylere besin gruplarından sebzelerin haşlanması ve pişirilmesinde kullanılan "Az suda haşlayıp, kendi suyunda pişirme", "Bol suda haşlayıp, suyunu dökme", "Buharda pişirme", "Hiç haşlamadan kendi suyunda pişirme" yöntemlerinden hangi uygulamayı tercih ettiği sorulmuştur. Araştırmaya katılan bireylerin \%34,9 (n=218)'u doğru olan yöntemi tercih ederken, \%65,1 $(\mathrm{n}=407)$ 'inin daha fazla besin ögesi kaybına sebep olacak yöntemleri tercih ettiği ortaya konulmuştur.

Yapılan bu çalışmaya katılan bireylere besin gruplarından sebzelerin haşlanmasında kullanılan "Soğuk su ilave edip haşlama", "Kaynar suya ilave edip haşlama”, "Kaynar suya tuz ilave edip sebzeyi ekleyerek haşlama" yöntemlerinden hangi uygulamayı tercih ettiği sorulmuştur. Araştırmaya katılan bireylerin \%28,8 ( $\mathrm{n}=180)^{\prime} \mathrm{i}$ doğru olan uygulamayı yaparken, \%71,2 $(\mathrm{n}=445)^{\prime}$ 'sinin yanlış olan uygulamaları tercih ettiği ortaya konulmuştur.

Baysal (2002) sebzeler pişirilirken mümkün olduğunca az suyun kullanılması gerektiğini ve kaynayan suya sebzelerin atılması gerektiğini belirtmiştir. Blauw vd., (1976)'nin yapmış oldukları çalışmada sebzeleri pişirmede kullanılan yöntemlerde en az besin ögesi kayıplarının; tencere içerisinde, basınç altında, kısa sürede ve az suda pişirme uygulaması ile sıcak suya sebze ekleyerek uygulanan pişirme yöntemi olduğu belirtilmiştir. En fazla besin ögesi kaybı ise bol suda haşlanarak uygulanan pişirme yöntemidir. Vashfam (2002) sebzelerin pişirme esnasında sık sık ağzının açılması, pişirme esnasında çok fazla karıştırılması, pişirme esnasında çok fazla suyun kullanılması gibi etkenlerin sebzelerdeki besin ögesinde büyük oranda kayıplara sebep olabileceğini belirtmektedir.

Yapılan bu çalışmaya katılan bireylere besin gruplarından sebze ve meyvelerin kurutulmasında uygulanan "Güneşte üstü kapalı”, "Güneşte üstü açık”, “Gölgede, üstü kapalı ve havadar yerde”, "Kurutma yapmiyorum" yöntemlerinden hangisini tercih ettiği sorulmuştur. Araştırmaya katılan bireylerin \%13,3 ( $\mathrm{n}=83)^{\prime}$ ü doğru olan uygulamayı yaparken, \%86,7 ( $\left.\mathrm{n}=542\right)^{\prime} \operatorname{sinin}$ yanlış olan uygulamaları tercih ettiği ortaya konulmuştur.

Köksal (2001), ülkemizde birçok ailenin sebze ve meyveleri yaz aylarında güneşli ve açı havalarda kuruttuğunu belirtmiştir. Ancak bu besinlerin açik havada doğrudan güneşe maruz bırakılarak kurutulmasıyla $C$ vitamini düzeyinde çok önemli düzeyde azalmaların olduğunu vurgulamıştır.

Yapılan bu çalışmaya katılan bireylere besin grupları içerisinde yer alan patatesi haşlamak için "Kabuğunu soyarak haşlama" ve "Kabuğunu soymadan haşlama" yöntemlerinden hangi uygulamayı tercih ettiği sorulmuştur. Araştırmaya katılan bireylerin \%61 (n=398)'i doğru olan yöntemi tercih ederken, \%39 ( $\mathrm{n}=244)^{\prime}$ unun yanlış olan uygulamayı tercih ettiği ortaya konulmuştur.

Koçak (2005), patates ve pancar gibi sebzelerin pişirilmesi esnasında besin kaybına uğrayabileceği gibi, pişirmeden önce uygulanan işlemlerin ve pişirmeye hazırlık esnasındaki beslenme sürelerinin de besin kaybına yol açabileceğini belirtmiştir. Ayrıca aynı çalışmada, patates ve pancar gibi sebzeler pişirmeden önce soyulup bekletildiğinde besin ögelerinde kayıplar yaşanacağını, ancak kabuğuyla birlikte haşlandığı zaman, kabuk kısmı kendiliğinden ayrılacağı için, besin ögelerindeki kayıpların da minimuma ineceğini belirtmiş̧tir. 
Yapılan bu çalı̧̧maya katılan bireylere besin grupları içerisinde yer alan eti çözdürmek için kullandıkları "Buzdolabında çözdürme", "Oda 1sısında çözdürme", "Sıcak suya islatarak çözdürme" ve "Çözdürmeden kullanma" yöntemlerinden hangi uygulamayı tercih ettiği sorulmuştur. Araştırmaya katılan bireylerin \%39 ( $n=244)^{\prime}$ u doğru olan uygulamayı yaparken, \%61 (n=398)'inin yanlış olan çözdürme yöntemlerini tercih ettiği ortaya konulmuştur.

Alpkent ve Karabağlı (1998) teknolojinin gelişmesiyle birlikte insanların gıdaları muhafaza etmek için farklı yöntem ve teknikler geliştirdiğini belirtmiştir. Ancak insanlığın var olmasından bu yana en çok kullanılan yöntemlerden biri olan dondurarak muhafaza yönteminin etkili olabilmesi için, etin içerisindeki özsuyuna zarar gelmeden dondurma işleminin yapılması gerektiği ve bu işlemin hızlı bir şekilde yapılması gerektiğinin önemi vurgulamıştır. Vashfam (2002) hayvansal ürünlerde en çok meydana gelen besin ögesi kayıplarının sebebinin dondurulmuş etleri çözdürme aşamasında olduğunu belirtmiştir. Bulduk (2002) ise etlerde çözdürme işleminde oluşabilecek kayıpları minimuma indirilmesi için buzdolabının alt kısmında çözdürme işleminin yapılması gerektiğini belirtmiştir.

Yapılan bu çalışmaya katılan bireylere besin grupları içerisinde yer alan eti saklamada "Bütün halde saklama", "Yemeklik parçalar halinde saklama" ve "Kavurup saklama" yöntemlerinden hangi uygulamayı tercih ettikleri sorulmuştur. Araştırmaya katılan bireylerin \%85,8 ( $n=536)^{\prime} \mathrm{i}$ doğru olan uygulamayı yaparken, \%14,2 ( $\mathrm{n}=89)^{\prime}$ sinin doğru olan saklama yöntemini tercih etmediği ortaya konulmuştur.

Baysal (2002), etler hemen tüketilmeyecekse yemeklik parçalar halinde yassı biçimde paketlenmiş olarak buzdolabında 1 hafta kadar, dondurucuda ise 3-4 ay kadar saklanabileceğini belirtmiştir.

Yapılan bu çalışmaya katılan bireylere besin grupları içerisinde yer alan eti ızgara usulüyle pişirmede "Ateşe yakın pişirme", "Ateşle et arasında 3-4 cm olacak şekilde pişirme", "Ateşle et arasında 5-10 cm olacak şekilde pişirme", "Ateşle et arasında $15 \mathrm{~cm}$ ve üzeri olacak şekilde pişirme" ve "Ateşle et arasındaki mesafeye dikkat etmeden pişirme" yöntemlerinden hangisini tercih ettikleri sorulmuştur. Araştırmaya katılan bireylerin \%14,7 ( $\mathrm{n}=92)^{\prime}$ 'si etleri ızgara ile arasında $15 \mathrm{~cm}$ ve üzeri mesafe olacak şekilde pişirirken, \%85,5 (n=533)'inin doğru olmayan pişirme yöntemlerini tercih ettiği ortaya konulmuştur.

Baysal (2002), mikroorganizmalardan kaynaklanabilecek risk etmenlerini azaltmak veya ortadan kaldırmak, besin ve besin ögesi kayıplarını minimuma indirmek, pişirme esnasında ortaya çıkabilecek zararlı bileşenleri önlemek için etlerin ızgara ile arasında minimum $15 \mathrm{~cm}$ ve üzeri mesafe olacak şekilde pişirilmesi gerektiğini belirtmiştir.

Yapılan bu çalışmaya katılan bireylere besin grupları içerisinde yer alan et ve balıkları kızartmada "Az yağda kızartma", "Bol yağda kızartma" ve "Kızartma yapmam" yöntemlerinden hangi uygulamayı tercih ettikleri sorulmuştur. Araştırmaya katılan bireylerin \%61,3 (n=383)' ü doğru olan uygulamayı yaparken, \%38,7 (n=242)'sinin doğru olan kızartma yöntemini tercih etmediği ortaya konulmuştur.

Açkurt (1989)'un etlerin ve balıkların farklı yöntemlerle pişirilmesiyle ortaya çıkacak besin ögesi kayıplarını belirlemek için yapmış olduğu çalışmada etlerdeki $B_{1}$ vitamini oranında $\% 50$ azalma, $\mathrm{B}_{2}$ vitamini oranında $\% 80$ azalma, $\mathrm{B}_{6}$ vitamini oranında ise \%40 azalma olduğunu tespit etmiştir. Balıkta ise bu azalma miktarları sırasıyla \%54, \%95 ve \%65'tir. Ayrıca bu çalışmada pişirme yöntemi ve pişirme süresinin ise genel olarak herhangi bir mineral kaybına sebep olmadığ 1 belirtilmiştir. 
Yapılan bu çalışmaya katılan bireylere besin grupları içerisinde yer alan pilav ve helvayı pişirmede "Kavurarak pişirme" ve "Kavurmadan pişirme" yöntemlerinden hangi uygulamayı tercih ettikleri sorulmuştur. Araştırmaya katılan bireylerin \%11,7 (n=73)'si doğru olan uygulamayı yaparken, \%88,3 (n=552)'ünün doğru olan yöntemi tercih etmediği ortaya konulmuştur.

Kavurma yöntemiyle kuru isıya maruz bırakılan un ve pirincin protein değeri daha da düşecektir. Ayrıca yağda kavrulan pirinç veya tahıl taneleri yağ da tutacağı için haşlama usulü pişirilmiş tahıllara göre enerjisi daha fazla olur. Hem besin ögelerinin korunması ve düşük kalorili ve sağlıklı olması için tahıllarda mümkün olduğunca kavurma yönteminin tercih edilmemesi gerekmektedir (Baysal, 1999).

Yapılan bu çalışmaya katılan bireylere besin grupları içerisinde yer alan makarnayı pişirmede kullanılan "Bol suda haşlayıp suyunu dökme", "Bol suda haşlayıp suyunu değerlendirme" ve "Az suda çektirerek pişirme" yöntemlerinden hangi uygulamayı tercih ettikleri sorulmuştur. Araştırmaya katılan bireylerin \%30,9 (n=193)'ü doğru olan uygulamayı yaparken, \%69,1 $(n=432)$ 'sinin doğru olan pişirme yöntemini tercih etmediği ortaya konulmuştur.

Makarnalar yapılırken uygulanan işlemlerden dolayı besin değerlerinde azalmalar görülmektedir. Orta kalitede makarnalar hacminin yaklaşık 1,5 katı su çekerken, iyi kalitede makarnalar ise ortalama hacminin 2 katı su çekmektedir. Makarna pişirirken bu hacimlerde yani az suda çektirerek pişirilmesiyle daha fazla oluşacak besin ögesi kayıplarının önüne geçilir (Baysal, 2002).

Yapılan bu çalışmaya katılan bireylere besin grupları içerisinde yer alan yumurtayı haşladıktan sonra "Haşlama suyunda bekletme" ve "Haşlama suyunda bekletmeme" yöntemlerinden hangi uygulamayı tercih ettikleri sorulmuştur. Araştırmaya katılan bireylerin \%71,7 ( $\mathrm{n}=448)^{\prime} \mathrm{si}$ yumurtayı kaynattıktan sonra haşlama suyunda bekletmezken, \%28,3 ( $\mathrm{n}=177)^{\prime}$ ünün yumurtayı haşladıktan sonra kendi suyunda beklettikleri ortaya konulmuştur.

Yapılan bu çalışmaya katılan bireylere besin grupları içerisinde yer alan sütü saklamada kullanılan "Oda sıcaklığında ağzı açı şekilde", "Buzdolabında ağzı açık şekilde", "Oda sıcaklığında ağzı kapalı şekilde" ve "Buzdolabında ağzı kapalı şekilde" yöntemlerinden hangi uygulamayı tercih ettikleri sorulmuştur. Araştırmaya katılan bireylerin \%86,4 $(n=540)^{\prime} \ddot{u}$ doğru olan uygulamayı yaparken, \%13,6 ( $n=85)^{\prime}$ sının bu uygulamayı yapmadığı ortaya konulmuştur.

Yapılan bu çalışmaya katılan bireylere besin grupları içerisinde yer alan sütü pişirmek için kullanılan "Kabarınca alma", "Kaynayınca hemen alma", "Kaynamaya başlayınca $5 \mathrm{dk}$. daha karıştırarak kaynatma ve alma" ve "Kaynamaya başlayınca 20-25 dakika daha karıştırarak kaynatma ve alma" yöntemlerinden hangi uygulamayı tercih ettikleri sorulmuştur. Araştırmaya katılan bireylerin \%59,7 ( $\mathrm{n}=373)^{\prime}$ 'si sütü bu şekilde pişirirken, \%40,3 ( $\mathrm{n}=252$ )'ünün bu uygulamayı yapmadığı ortaya konulmuştur.

Baysal (2002), pastörize olmayan sütlerin en az 5 dakika boyunca kaynatılıp buzdolabında 1-2 gün süreyle cam kaplar içerisinde ağzı kapalı şekilde saklanabileceğini, pastörize sütlerin ise ağzı açıldıktan sonra 2-3 gün süreyle buzdolabında ağzı kapalı şekilde saklanabileceğini belirtmiştir.

Yapılan bu çalışmaya katılan bireylere besin grupları içerisinde yer alan sütü pişirdikten sonra soğutmak için "Soğuyana kadar kapağı açık bekletme", "Sıcakken kapağını kapatıp buzdolabına kaldırma", "Soğuyana kadar kapağı kapalı bekletip sonra buzdolabına kaldırma" ve "Kapağını kapatıp soğuk su dolu kabın içerisinde hızlıca soğutup buzdolabına kaldırma" yöntemlerinden 
hangisini tercih ettikleri sorulmuştur. Araştırmaya katılan bireylerin \%31,8 (n=199)'si doğru olan uygulamayı yaparken, \%68,2 ( $\mathrm{n}=426)$ 'sinin bu uygulamayı yapmadığı ortaya konulmuştur.

Yazman (1994)'ın sütleri pişirme ve saklama esnasında meydana gelen vitamin kayıplarını ortaya koymak için yapmış olduğu çalışmada en çok vitamin kayıplarının $B_{1}, B_{2}$, $B_{3}$ ve folik asitte meydana geldiğini ortaya koymuştur. Ayrıca Yazman pişirme işleminin süresine bağlı olarak bu vitaminlerde meydana gelen kayıpların düzeylerinin değişebileceğini belirtmiştir.

Yapılan bu çalışmaya katılan bireylere besin grupları içerisinde yer alan yoğurdu alırken "Kâse yoğurt" ve "Süzme yoğurt" arasından hangisini tercih ettikleri sorulmuştur. Araştırmaya katılan bireylerin \%78,7 (n=492)'si kâse yoğurt tercih ederken, \%21,3 ( $\mathrm{n}=133)$ 'ünün tercih ettiği yoğurdun süzme yoğurt olduğu ortaya konulmuştur.

Süzme yoğurt yapılırken, içeriğinde yer alan su uzaklaştırıldığı için başta B grubu vitaminleri olmak üzere birçok makro ve mikro besin ögesi kaybı görülmekte ve besin değeri kâse yoğurda göre azalmaktadır. Yoğurt tüketiminde kâse yoğurt tercih edilmeli ya da süzülen yoğurdun suyu başka besinlerde kullanılması durumunda besin ögesinde meydana gelebilecek kayıplar minimuma indirilebilir (Baysal, 2002).

Yapılan bu çalışmaya katılan bireylere besin grupları içerisinde yer alan peyniri muhafaza etmede "Mutfakta serin bir yer", "Buzdolabı", "Dondurucu" ve "Kiler veya izbe" ortamlarından hangisini tercih ettikleri sorulmuştur. Araştırmaya katılan bireylerin \%89 (n=556)'u peyniri buzdolabında muhafaza ederken, \%11 (n=69)'inin peyniri buzdolabında muhafaza etmediği ortaya konulmuştur.

Yazman (1994)'ın yapmış olduğu çalışmada yoğurt yapma ve saklama aşamalarında en çok kaybın olduğu vitaminler arasında $B_{1}, B_{2}$, $B_{3}$ ve folik asit olduğu, kullanılan yöntemlerin ve pişirme sürelerinin bu vitaminlerde meydana gelecek kayıpların düzeyini artırabileceğini belirtilmiştir.

Tablo 2. Ölçeğe İlişkin Betimsel İstatistikler

\begin{tabular}{cccccc}
\hline & N & En düşük puan & En yüksek puan & Ort. & ss \\
\hline Ölçek Toplam & 625 & 3 & 14 & 8,88 & 2,18 \\
\hline
\end{tabular}

Tablo 3. Ölçeğin Cinsiyet, Gelir ve PCR Testine Göre Farklılaşma Durumuna Ait Bağımsız Örneklem T-Testi Sonuçları

\begin{tabular}{|c|c|c|c|c|c|c|c|c|}
\hline & & \multicolumn{7}{|c|}{ Levene test } \\
\hline & & $\mathrm{n}$ & $x$ & Ss & $\mathrm{F}$ & $\mathrm{p}$ & $\mathrm{t}$ & $\mathrm{df}$ \\
\hline \multirow[t]{2}{*}{ Cinsiyet } & Kadın & 364 & 9,24 & 0,10 & \multirow[t]{2}{*}{15,62} & \multirow[t]{2}{*}{$0,000^{*}$} & \multirow[t]{2}{*}{4,90} & \multirow[t]{2}{*}{623} \\
\hline & Erkek & 261 & 8,38 & 0,14 & & & & \\
\hline \multirow{2}{*}{$\begin{array}{l}\text { Gelir } \\
\text { Düzeyi }\end{array}$} & 5.000 Alt1 & 242 & 8,48 & 2,27 & \multirow[t]{2}{*}{6,94} & \multirow[t]{2}{*}{$0,009^{*}$} & \multirow{2}{*}{$\begin{array}{c}- \\
3,64\end{array}$} & \multirow[t]{2}{*}{623} \\
\hline & 5.000 ve üzeri & 383 & 9,13 & 2,10 & & & & \\
\hline \multirow{2}{*}{$\begin{array}{l}\text { PCR-BT } \\
\text { Testi }\end{array}$} & Pozitif & 189 & 8,51 & 2,37 & \multirow[t]{2}{*}{7,73} & \multirow[t]{2}{*}{$0,005^{*}$} & - & \multirow[t]{2}{*}{623} \\
\hline & Negatif & 436 & 9,04 & 2,08 & & & 2,80 & \\
\hline
\end{tabular}


Çalışmaya katılan bireylerin, besinlere yönelik uygulamalara vermiş olduğu doğru cevaplar "1 Puan", yanlış cevaplar ise "0 Puan" olarak ölçeklendirilmiştir. Analiz sonuçlarına göre en düşük puan olan birey sadece 3 uygulamayı doğru yaptı̆̆ için 3 puan almıştır. En yüksek puan ise 14 uygulamayı yapan bireye aittir. Çalışma sonuçlarına göre bireylerin doğru yapma ortalamaları ise $8,88^{\prime}$ dir.

Besin hazırlama pişirme ve saklamaya yönelik katılımcılara uygulanan ankette, doğru uygulamalara ilişkin verilen cevapların ortalamalarının cinsiyet, gelir ve PCR testine göre farklılaşma durumuna ait bağımsız örneklem $T$-testi sonuçları incelendiğinde; üç demografik değişkenin ortalamalarının anlamlı farklılık gösterdiği $(p<0,05)$, Bu bağlamda;

- Kadınların (ort. 9,24) erkeklere (ort. 8,38) göre doğru uygulamalara yönelik ortalamalarının daha yüksek olduğu saptanmıştır.

- Gelir düzeyi 5.000 TL ve üzeri olanların (ort. 9,13) gelir düzeyi 5.000 TL altında olanlara (ort. 8,48) göre doğru uygulamalara yönelik ortalamasının daha yüksek olduğu saptanmiştır.

- Covid-19 test sonucu negatif (-) çıkanların (ort. 9,04) daha önce PCR veya BT yöntemleriyle Covid-19 test sonucu pozitif (-) çıkanlara (ort. 8,51) göre doğru uygulamalara yönelik ortalamasının daha yüksek olduğu ortaya konulmuş̧tur.

Besinlere yönelik tercih edilen yöntemlerde doğru uygulamanın yapılmasıyla cinsiyet ilişkisi analiz sonuçlarına göre araştırmaya katılan erkek ile kadınların sorulara verdiği cevaplarda kadınların erkeklere göre besinlere yönelik uygulamaları daha doğru yaptığı ortaya konulmuştur.

Besinlere yönelik tercih edilen yöntemlerde doğru uygulamanın yapılmasıyla bireylerin gelir düzeyi arasındaki ilişki incelendiğinde, analiz sonuçlarına göre, araştırmaya katılan gelir düzeyi 5000 TL üzerinde olan bireylerin, gelir düzeyi 5000 TL ve altında oplan bireylere göre besinlere yönelik uygulamaları daha doğru yaptığı ortaya konulmuştur.

Besinlere yönelik tercih edilen yöntemlerde doğru uygulamanın yapılmasıyla, PCR testi ve BT sonucunun incelenmesi sonucu koronavirüs hastalığ 1 varlığının tespit edilmesi arasındaki ilişkiyi ortaya koyan analiz sonuçlarına göre, koronavirüs hastalı̆̆ına yakalanan bireylerin doğru uygulamaları daha az yaptığı belirlenmiştir.

\section{SONUÇ ve ÖNERILER}

Koronavirüs pandemisi ilk olarak Çin'in Hubei eyaletinde çıkmasına karşın kısa bir süre içerisinde bütün dünyayı etkisi altına almıştır. Dünya Sağlık Örgütü koronavirüsten korunmak için; maske takılması, sosyal mesafe kurallarına uyulması, yüzeylere temastan kaçınılması, temizlik kurallarına uyulması ve sağlıklı beslenmeye dikkat edilmesi gibi hususlarda uyarılarda bulunmaktadır. Sosyal, kültürel ve ekonomik alanlarda başta olmak üzere, toplumu büyük ölçüde etkileyen koronavirüs pandemisinde, hastalığın yayılmasını engellemek için kafe, restoran gibi yemek üretim-servisi yapan işletmelere getirilen kısıtlamalar, bireylerin hazır gıda tüketiminin azalmasına ve evde yemek hazırlamaya ayrılan vaktin artmasına sebep olmuştur. Bireylerin temizlik kurallarına uyması, maske takması ve sosyal mesafe kurallarına uymasının yanında gıdalardan kaynaklı bulaşların önüne geçmek için evde yemek yapma uygulamasına yöneltmiştir. Ancak çalışmanın sonuçları incelendiğinde bireylerin besin gruplarından süt ve süt ürünlerini, etleri, kuru baklagilleri, sebze ve meyveleri, ekmek grubundan pilav, makarna ve patatesi haşlama, pişirme ve saklama uygulamalarında yanlışlar yaptığı belirlenmiştir. Bireylerin besinlere yönelik yapmış olduğu bu yanlış uygulamalar, besinlerde vitamin ve mineral 
kayıplarına yol açmakta ve besin değerini azaltmaktadır. Besin kalitesi düşük, vitamin-mineral düzeyi azalmış besin gruplarının vücuda alınması bağışıklık sistemini güçlendirmede yetersiz kalacağı için, başta koronavirüs olmak üzere diğer enfeksiyonel hastalıklara karşı vücudumuz savunmasız kalacaktır. Nitekim bu çalışmanın sonuçlarına göre besinleri satın alma, hazırlama, pişirme ve saklama uygulamalarında yanlış yöntemlerin kullanılması veya uygun olmayan yöntemlerin tercih edilmesi sonucu bireylerin koronavirüs hastalığına yakalanma oranının arttığı ortaya konulmuştur. Bunun sebepleri arasında koronavirüsün besin yüzeylerine tutunması ve besinlere yönelik yanlış uygulamaların besinleri koronavirüsten arındırılmasında yeterli olmaması gösterilebilir. Bunun yanında bireylerin bilinç düzeyinin düşük olması sebebiyle besinlere yönelik hijyen kurallarının sağlanamaması sonucu besin yüzeyinden temas kaynaklı bulaşların olduğu sonucuna da ulaşılabilir. Ayrıca bu sonuçlara göre besinlere yönelik doğru uygulamaları yapan bireylerin koronavirüs hastalığına yakalanma oranlarının daha düşük olduğu ortaya konulmuştur. Yapılan çalışmanın sonuçlarına göre erkeklerin kadınlara göre besinlere yönelik uygulamalarda daha fazla yanlış yaptığı belirlenmiştir. Araştırmanın yapıldığı bölgede erkeklerin çalışma veya iş hayatındaki oranının fazla olması dolayısıyla besinlere yönelik hazırlama ve pişirme gibi uygulamalarda kadınlara göre yetkinliğinin daha az olması bu durumun sebebi olarak gösterilebilir. Yapılan çalışmanın sonuçlarına göre gelir düzeyi yüksek olan bireylerin, gelir düzeyi düşük olan bireylere göre besinlere yönelik uygulamalarda daha az yanlışlar yaptığı ortaya konulmuştur. Çalışma sonuçları toplumun genelinde gelir düzeyi yüksek olan bireylerin kaynaklara ve doğru bilgilere ulaşılabilirliğinin yüksek olmasının etkisinin, besinlere yönelik uygulamalarda da geçerli olduğunu göstermektedir. Buna göre gelir düzeyi yüksek bireylerin doğru bilgiye daha kolay ulaştığı, bilgi ve bilinç düzeyi yüksek olduğu için de besinlere yönelik uygulamaları daha doğru yaptığı söylenebilir. Ayrıca besinlere yönelik bazı doğru uygulamaların maliyetli olması, yani doğrudan veya dolaylı olarak ekonomik düzeyle alakalı olması, doğru yöntemlerin uygulanabilirliğini azaltmaktadır. Bu çalışma sonucuna göre bazı bireylerin besinlere yönelik uygulamalarda yanlış yöntemleri yapmasının sebebiyle gelir düzeyinin düşük olması ilişkilendirilebilir. Çalışma sonuçlarıyla ilişkilendirilen demografik değişkenlerin ortak noktasının, bireylerin bilinç düzeyleri veya bilinç düzeylerini etkileyen değişkenler olduğu yorumu çıkarılabilir. Bu yüzden bireylerin besinleri hazırlama, pişirme ve saklama uygulamalarında daha fazla bilinçlendirilmesi gerekmektedir. Bunun için bireylerin besinleri hazırlama, pişirme ve saklama uygulamasına yönelik uygulamaları öğrenmede kolayca ulaşabileceği kitap, e-kitap sayısı arttırılabilir ve mobil programlar geliştirilebilir. Sosyal medya veya tv kanalları aracılığıyla besinleri satın alma, hazırlama, pişirme ve saklama uygulamalarının anlatıldığı belgesel veya kamu spotları kullanılabilir. Ayrıca Halk Sağlığı Müdürlüklerince veya Toplum Sağlı̆̆ Merkezlerince kent merkezi veya kırsal kesimlerde yaşayan bireylere toplu olarak eğitimlerin verilmesi bireylerin ve toplumun bilgi düzeyini artırmasını sağlayacaktır. Ayrıca ortaokul veya lise düzeyindeki öğrencilere bu eğitimlerin verilmesiyle erken çağlarda bireylerin daha bilinçli olması sağlanacaktır.

\section{Araştırmanın Sınırlılığı ve Gelecekte Yapılacak Araştırmalar için Öneriler}

Yapılan çalışmada bireylerin besinlere yönelik uygulamaları ile koronavirüse yakalanma durumları arasındaki ilişki incelenmiş olup, koronavirüs hastalığının bulaşmasında etkili olabilecek diğer bulaş faktörlerine (maskenin takılması, sosyal mesafe kurallarına ve temizlik kurallarına uyulması) eşit oranda uyum sağlandığı ve bunların tam olarak doğru uygulandığ kabul edilmiştir. Ayrıca pandemi döneminde ve öncesinde bu konuyla ilgili yeterli çalışmanın olmaması çalışmanın kısıtlılıklarından olup bu konuyla ilgili daha fazla çalışmaya ihtiyaç olduğu düşünülmektedir. Çalışmanın örneklem kümesini oluşturan bireylerin çoğunluğu aktif iş hayatında bulunduğu için diğer bulaş faktörlerine maruziyetin daha yüksek olabileceği göz 
önünde bulundurulduğunda, maruziyetin daha az görülebileceği meslek grupları üzerinde (ev hanımı, emekli vb.) çalışma yapılarak çalışma sonuçları desteklenebilir veya farklı sonuçlara ulaşılabilir.

\section{KAYNAKÇA}

Açkurt, F. (1989). Değişik Pişirme Yöntem ve Araçlarının Makarnanın Vitamin ve Mineral İçeriklerine Etkisi, TüBİTAK Marmara Araştırma Merkezi Beslenme ve Gıda Teknolojisi Bölümü Dergisi, Gebze.

Aktaş, A. (2001). Ağırlama Hizmet İşletmelerinde Yiyecek ve İçecek Yönetimi, Antalya: Livane Matbaasi.

Alpkent N. ve Karabağlı A. (1998). Türkiye ve AB'de Dondurulmuş Gıda Sanayinin Durumu ve Dış Ticaretinde Gelişmeler, Ankara: Milli Prodüktivite Merkezi Yayınları.

Altay, B. (1992). Kadınların Yiyecekleri Hazırlama, Pişirme, Saklama ve Sunma Konularındaki Bilgi ve Davranışları, Bilim Uzmanlığı Tezi, Hacettepe Üniversitesi Sağlık Bilimleri Enstitüsü, Hemşirelik Programi, Ankara.

Ateş, M., Ballar, E. ve Pekcan, G. (1986). Sosyo-ekonomik Yönden Farklı Semtlerde Yaşayan Ev Kadınlarının Besin Hazırlama, Pişirme ve Saklama Yöntemlerinin Saptanması, Beslenme ve Diyet Dergisi, 15(1): 71-83.

Ayaz Topçu, A., Bilgili, N. ve Köksal, E. (2003). 15-49 Yaş Grubu Ev Hanımlarının Besin Hazırlama, Pişirme ve Saklama Yöntemleri Konusunda Bilgi, Tutum ve Davranışlarına Yönelik Bir Araştırma, Türk Hijyen Deneyse ve Biyoloji Dergisi, 60(7): 77-86.

Baysal, A. (1990). Beslenme, Ankara: Öztek Matbaası.

Baysal, A. (1999). Beslenme. (8.Baskı), Ankara: Hatipoğlu Yayınları.

Baysal, A. (2002). Genel Beslenme. (11.Baskı), Ankara: Hatipoğlu Yayınları.

Baysal, A. (2013). Yüz Soruya Yüz Yanıtla Sağlıklı Beslenme, Ankara: Hatiboğlu Yayınları.

Blauw, Y.H., Keller, G.H.M. and Kovvenhoven, T. (1976). A Comparative Study on Effects of Methods of Cooking of Vegetables and Potatoes on Pretention of Nutrient and Organoleptic Properties Voeding, 6(37): 198-314.

Bulduk, S. (2002). Gıda Teknolojisi. (1.Baskl), Ankara: Detay Yayıncılık.

Bulduk, S. (2004). Gıda Teknolojisi, Ankara: Detay Yayıncilık.

Chan, J.F., Yuan, S., Kok, K.H., To, K.K., Chu, H., Yang, J., Xing, F., Liu, J., Yip, C.C., Poon, R.W., Tsoi, H.W., Lo , S.K., Chan, K.H., Poon, V.K., Chan, W.M., Ip, J.D., Cai, J.P., Cheng, V.C., Chen, H., Hui, C.K., Khalili N., ... Yuen, K.Y. (2020). A Familial Cluster of Pneumonia Associated with the 2019 Novel Coronavirus Indicating Person-to-Person Transmission: a Study of a Family Cluster, The Lancet, Londra, İngiltere, 395(10223), 514-523. https://doi.org/10.1016/S01406736(20)30154-9.

Çelebi, F. (2014). Geleneksel Türk Mutfă̆ından Seçmeler: Besin Ögeleri Açısından Değerlendirilmesi, Ankara: Detay Yayıncılık. 
Ç1ltık, N. (2009). İstanbul Kâ̆ğıthane İlçesinde Çalışan ve Çalışmayan Kadınların Beslenme Bilgi Düzeyleri ve Beslenme Alışkanlıklarının Saptanması, Yayınlanmamış Yüksek Lisans Tezi, Selçuk Üniversitesi Sosyal Bilimler Enstitüsü, İstanbul.

Dölkeleş, A. (2010). Üretim Teknikleri, (Ed. M. Sarışık, Ş. Çavuş ve K. Karamustafa), Profesyonel Restoran Yönetimi: İlkeler ve Örnek Olaylar İçinde Uygulamalar, Ankara: Detay Yayıncılık.

Dönmez, M.D., Öney, H. ve Ünlü, D. (2012). Yiyecek Üretim Temelleri, Eskişehir: Anadolu Üniversitesi Yayınları.

Ersoy, G. (1999). Gecekondu Ailelerinde Kadınların Yiyecek Hazırlama ve Pişirmeye İlişkin Bazı Uygulamaları Üzerine Bir Araştırma, Türkiye Sosyal Araştırmalar Dergisi, 3(1999): 67-81.

Eryılmaz, L.C. (2004). Yemek Pişirme Teknikleri-Çeşitleri Beslenme Yemek Görgü Kuralları, İstanbul: Remzi Kitabevi.

Gisslen, W. (2011). Professional Cooking, New Jersey: John Wiley \& Sons, Inc., Hoboken.

Güneyli, U. ve Yücecan S. (1987). Ankara'nın Farklı Sosyo-Ekonomik Semtlerindeki Ailelerin Gelir Düzeylerine Göre Besin Harcama Payları, Beslenme ve Diyet Dergisi, 16(1): 18-25.

Gürman, Ü. (2006). Yemek Pişirme Teknikleri ve Uygulaması, İstanbul: Milli Eğitim Bakanlığı Yayınları.

Hunter, G. and Tinton, T. (2011). Professional Chef. (9.Edition), New Jersey Wiley: Culinary Institute of America.

Kutlu, Z. (2004). Ankara İline Bă̆̆l Şereflikoçhisar İlçesi ve Köylerinde Yaşayan Evli Kadınların Beslenme Bilgi Düzeyleri, Besin Hazırlama, Pişirme ve Saklama Uygulamalarının Karşılaştırılması, Yayınlanmamış Yüksek Lisans Tezi, Ankara Üniversitesi Sağlık Bilimleri Enstitüsü, Ankara.

Koçak, H. (2005). Amasya İli Merkez İlçesi ve Köylerinde Yiyecek Hazırlama, Pişirme ve Saklama Uygulamaları, Yüksek Lisans Tezi, Ankara Üniversitesi Fen Bilimleri Enstitüsü, Ankara.

Köksal, O. (2001). Gıda ve Beslenme, Kayseri: Erciyes Üniversitesi Yayınları.

Malatyalığlu, N. (1991). Erzincan İli Merkez İlçesi Köylerindeki Evli Kadınların Beslenme Bilgi Düzeyleri ile Yiyecek Hazırlama, Pişirme ve Saklama Uygulamalar Üzerinde Bir Araştırma, Yayınlanmamış Yüksek Lisans Tezi, Ankara Üniversitesi Sağlık Bilimleri Enstitüsü, Ankara.

Maviş, F. (2008). Endüstriyel Yiyecek Üretimi, Ankara: Detay Yayıncılık.

MEGEP (2012). Süt Tozu ve Gıda Teknolojisi, Ankara: Milli Eğitim Yayınları.

Sökmen, A. (2011). Yiyecek ve İ̧ecek Servisi, Ankara: Detay Yayıncllık.

Tezcan, S. (1985). Türkiye'de Bebek ve Çocuk Ölümleri, Ankara: Uçbilek Matbaası.

Türkan, C. (2012). Mutfak Teknolojileri, Ankara: Sistem Ofset Yayınları.

WHO (World Health Organization). (2021). Novel coronavirus situation report-2. January22,2020.https://www.who.int/docs/defaultsource/coronaviruse/situationreports/2020012 2-sitrep-2-2019- ncov.pdf (Erişim Tarihi: 10.06.2021). 
Williams, C. (2011). Mutfak Strları, İstanbul: NTV Yayınları.

Vashfam, R.S. (2002). Ankara ve Tebriz (İran)'de Yaşayan Evli Kadınların Beslenme Bilgi Düzeyleri, Besin Hazırlama ve Pişirme Uygulamalarının Karşılaştırılması, Yayınlanmamış Yüksek Lisans Tezi, Ankara Üniversitesi Sağlık Bilimleri Enstitüsü, Ankara.

Yücecan, S. (1989). Beslenme Sorunları ve Boyutları, Ankara: Başbakanlık Çiçek Basımevi. 